\title{
Long-term social welfare and environmental policy in Quang Nam
}

\author{
Viet Hanh $\mathrm{Ho}^{1, *}$ and Thi Song Thuong Phan ${ }^{1}$ \\ ${ }^{1}$ Institute of Social Sciences of the Central Region, Nam Ky Khoi Nghia str., Ngu Hanh Son Dist, Da \\ Nang city, 50000, Viet Nam
}

\begin{abstract}
Quang Nam has been entering the stage of economic restructuring for the sake of effectively exploiting and utilizing the province's potential and strengths toward rapid and sustainable socioeconomic development. Ensuring social welfare is one of the core goals in building a fair, progressive, and civilized society associated with improving local people's material and spiritual life in the new period. The article focuses on assessing the current situation of the province's social welfare policies in 2015-2019 with the aim of identifing major challenges in the economic restructuring up to 2030. Accordingly, the paper proposes various solutions to improving those social protection policies in Quang Nam up to 2030, with a vision to 2045 .
\end{abstract}

\section{Introduction}

Improving social welfare policies is a major pillar in developing a socialist-oriented market economy, making a significant contribution to successfully developing a civilized, progressive, and equitable society ensuring a social - political stability as well as its people's life. According to the International Labor Organization (ILO), "Social welfare involves delivering benefits to households and individuals through their government or various groups to offset a substantial reduction of income from work and improve their living standards". In terms of structure, in Viet Nam, the current social welfare system is compatible and consistent with the ILO's concept of social welfare including two principal parts: Social insurance (covering short-term and long-term subsidies, unemployment insurance, and health insurance) and Social assistance (regular and emergency assistance). On a large scale, in Viet Nam, social welfare covers other range of programs such as social incentives, poverty reduction, programs designed to support localities under severe difficulties, savings funds, and other types of insurance state that social welfare system is integrated from four pillars including allocation, delivery, provision, and finance. Allocation involves identifying who will benefit from social welfare, including their financial conditions for receiving assistance, health conditions (disabled or not), performance behaviors (whether they are actively looking for work while receiving social insurance allowances). Delivery refers to types and levels of the benefits provided for beneficiaries. Provision entails who will provide the benefits to the beneficiaries.

*Corresponding author: hanhcjs@yahoo.com 
Ultimately, finance determines who will sponsor the social welfare system

The social welfare that has gained attention from Viet Nam's Party and government has been considered as a top priority in developing a socialist-oriented economy. In recent years, implementation of Quang Nam's social welfare policies has achieved positive results. Accordingly, the rate of poor households based on multi-dimensional standards has decreased to $10.3 \%$ in 2018 and $3.4 \%$ compared to 2016 . The coverage rate of social insurance, health insurance, and unemployment insurance has also increased over the years. In $2018,92.8 \%$ of the province's population participated in health insurance and $19.43 \%$ of the working-age population participated in social insurance. Policies of pension, social subsidies, and incentives have been effectively implemented, especially, policies for people contributed to the country's revolution, Vietnamese heroic mothers; policies for supporting housing construction for poor households and ethnic minorities, and those for children under extreme difficulties. As a result, those groups of populations' material and spiritual lives have improved; remarkably, living standards of nearly $97.3 \%$ of the policy beneficial families are considered equal to or higher than the average one of residential areas.

Nevertheless, the province's social welfare policies have faced various challenges such as (i) there are a large number of poor people, ethnic minorities, poor districts, communes, and villages who need to be protected. The province's poverty rate (estimated $9.1 \%$ in 2019 ) is considered quite high compared to other provinces in the South Central Viet Nam (5.5\%) and compared to the national average (5.7\%); (ii) people in mountainous and highland areas as well as ethnic minority groups have struggled numerous difficulties in their lives; (iii) levels of social assistances, allowances and protection remains low, and lots of children have been living in extremely difficult conditions; (iv) number of people voluntarily participating in social insurance tend to decline (in 2018, the group only accounts for about $0.23 \%$ of the total number of targeted participants); (v) the proportion of people participating in unemployment insurance is still low, estimated about $17.57 \%$ of the total workforce; (vi) debts of social insurance, health insurance, and unemployment insurance have been outstanding; in particular, (vii) overspending the province's insurance fund in the last three years has become its severe challenge under shrinking central and local budgets. Those challenges stem from various reasons. Some of them can be listed as follows: Mechanisms for implementing a number of policies are inadequate; procedures of investigating and classifying poor households are not following regulations; plenty of people have excessively relied on social policies; investment in executing policies are limited, mainly depending on the state budget; staff members responsible for applying social policies are unqualified or lack professional skills to meet task requirements; coordination in policy implementation is ineffective, and inspection and examination have not been paid much attention.

Quang Nam has been restructuring the economy to effectively utilize and benefit from its potential and strengths toward rapid and sustainable socio-economic development. Ensuring social welfare is one of the key goals in rapid and sustainable development. Nevertheless, during the economic restructuring for 2021-2030, globalization, ongoing worldwide pandemic, and climate change, Quang Nam has struggled numerous challenges and obstacles. What orientations and solutions should the province develop and propose in an effort to improve the social welfare system? What is the appropriate model of social welfare toward rapid and sustainable socio-economic development in the coming years? Those questions will guide the study. In addition, the article attempts to evaluate the current situation of the province's social welfare system based on three primary groups, including poverty reduction; insurance; old-age pensions, subsidies, and social protection. Besides, the article focuses on analyzing two out of the four principal pillars of the system known as finance and delivery. In this sense, the paper identifies major challenges and proposes good and sound solutions to improving and enhancing the social welfare policies in Quang Nam 
up to 2030 , with a vision to 2045 .

\section{Materials and Methods}

This paper discusses on entering the stage of economic restructuring for the sake of effectively exploiting and utilizing of Quang Nam province's potential and strengths toward rapid and sustainable socio-economic development. Based on legal, public policies and management approach, this paper uses the comparison and analysis methods to analyze and compares mechanism management, which related to social welfare system with two principal parts: Social insurance (covering short-term and long-term subsidies, unemployment insurance, and health insurance) and Social assistance (regular and emergency assistance)

\section{Results}

\subsection{The situation of social welfare policies in Quang Nam in the period of 2015-2019}

The rate of expenditure on social welfare to total state budget expenditure has been increasingly (a rise of $5.26 \%$ in 2019 compared to $4.88 \%$ in 2016). Total budget expenditure of state and the province for 05 projects of the National Targeted Program for Sustainable Poverty Reduction was over 1,285 trillion VND (75.18 percent of which are development investment capital and the rest are non-business capital). Table 1 shows that state budget expenditure on poverty reduction policies accounts for $92.88 \%$ of total state budget of the Program.

Table 1. Budget expenditure for poverty reduction policies in 2018 (Source: Synthesis of reports of Department of Labors, War Invalids and Social Affairs (2019)).

\begin{tabular}{|c|c|c|}
\hline Policies & Official documents & Expenditure (Bill. Dong) \\
\hline $\begin{array}{lll}\begin{array}{l}\text { Policy on } \\
\text { reduction }\end{array} & \text { Poverty } \\
\end{array}$ & $\begin{array}{l}\text { Resolution No.80/NQ-CP dated } \\
\text { on } 19 / 5 / 2011 \text { by the Government }\end{array}$ & $3,325.684$ \\
\hline $\begin{array}{lll}\begin{array}{l}\text { Policy on } \\
\text { reduction }\end{array} & \text { Poverty } \\
\end{array}$ & $\begin{array}{l}\text { Resolutions issued by Quang Nam } \\
\text { People's Council }\end{array}$ & 22.651 \\
\hline $\begin{array}{lr}\begin{array}{l}\text { Policy on } \\
\text { sustainable } \\
\text { alleviation }\end{array} & \text { poverty } \\
\end{array}$ & $\begin{array}{l}\text { Resolution No. } 13 / 2017 / \mathrm{NQ}- \\
\text { HĐND issued by Quang Nam } \\
\text { People's Council }\end{array}$ & 206.372 \\
\hline $\begin{array}{l}\text { Policy on monthly } \\
\text { allowance for }\end{array}$ & $\begin{array}{l}\text { Resolution No. } 18 / 2018 / \mathrm{NQ}- \\
\text { HĐND issued by Quang Nam } \\
\text { People's Council }\end{array}$ & 2.422 \\
\hline $\begin{array}{l}\text { Policy on supporting the } \\
\text { standard of living } \\
\text { improvement }\end{array}$ & $\begin{array}{l}\text { Resolution No. } 49 / 2018 / \mathrm{NQ}- \\
\text { HĐND issued by Quang Nam } \\
\text { People's Council }\end{array}$ & 23.277 \\
\hline Total & & $3,580.406$ \\
\hline
\end{tabular}

The provincial government has implemented policies and projects on poverty reduction efficiently, especially in poverty communes in mountainous and coastal areas. The local government has also carried out policies on training and creating jobs to increase income for poor people. As a result, the rate of multi-dimensional poor households was $9.1 \%$ in 2019 , decreasing by 4.6 percentage points compared to the rate in 2016 . However, this rate was relatively high compared to the rate of other provinces in the South Central region $(5.5 \%)$, and only lower than the rate of Ninh Thuan province $(9.8 \%)$ and the average rate of the whole country $(5.7 \%)$ (See Figure 1). 


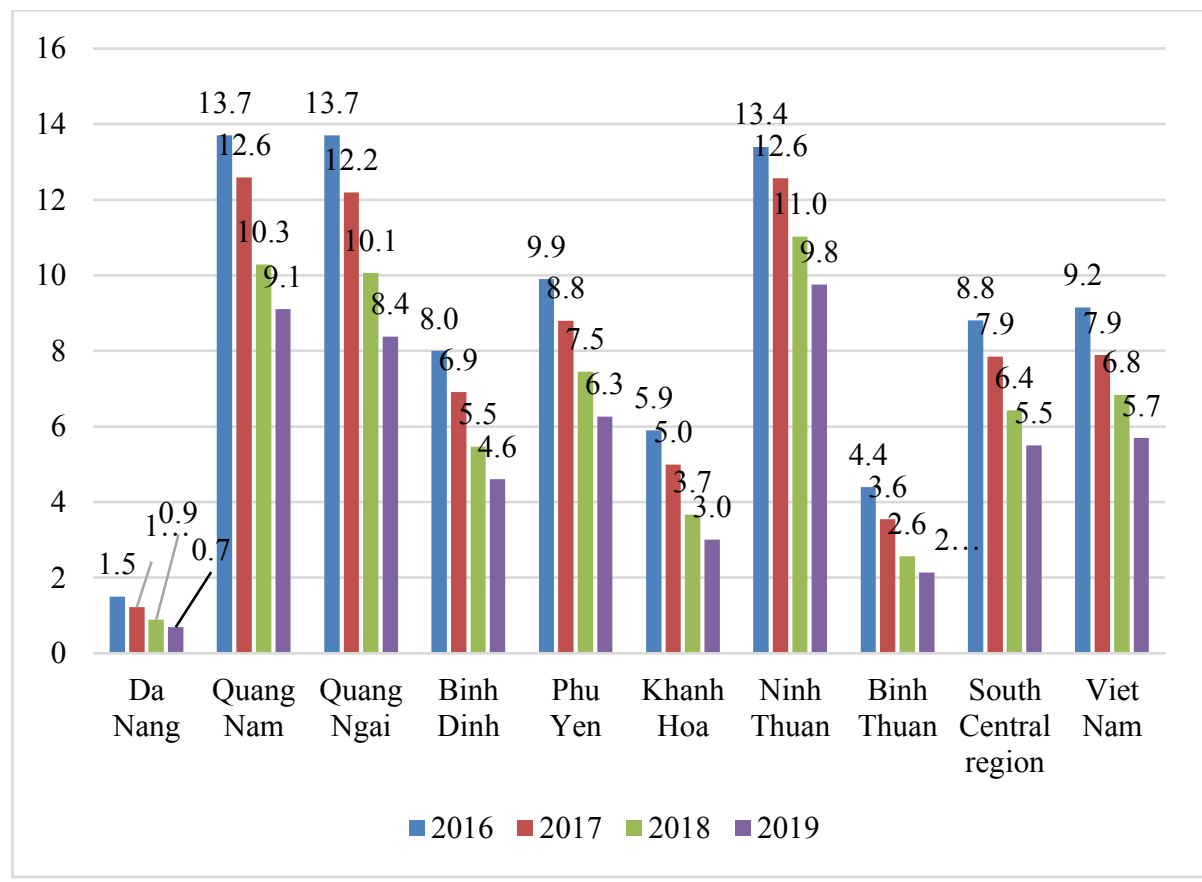

Fig. 1. The rate of poor households in South Central region in 2016-2019 (Source: Quang Nam statistical yearbook 2019).

As for policies on encouraging sustainable poverty alleviation, there are officers in charge of implementing poverty reduction in each communes in Quang Nam. In 2017, there were 3,989 poor households and 5,980 pro-poor households registered to escape poverty sustainability. The provincial government has allocated 85.495 billion dong to pay for policies and orders to encourage sustainable poverty alleviation by Resolution No.13: 97.62 percent of which belongs to provincial budget and the rest belongs to district budget (Huu Diep, 2018). Up to now, the whole province has 30 poor communes registered to escape poverty sustainably: 11 communes of which belong to the 257 Program and the rest belong to the 135 Program. However, the rate of poor household has not met the assigned target and relatively higher than the average rate of the whole country as well as of the South Central region.

\subsection{Social insurance, health insurance, unemployment insurance}

Number of social and health insured people had increased in the period of 2010-2019. However, the rate of social voluntary insured people was relatively low and decreased, accounting for $0.24 \%$ in 2018 (see Table 2). Number of unemployment insured people increased by 1.3 times for 4 years. The rate of unemployment insured people was quite low, accounting for $17.57 \%$ of total participation labor force.

Table 2. Number of insured persons in Quang Nam province Unit: Thousan persons (Source: Quang Nam statistical yearbook 2018, 2019 \& Quang Nam Social insurance).

\begin{tabular}{|l|c|c|c|c|c|}
\hline Indicators & $\mathbf{2 0 1 0}$ & $\mathbf{2 0 1 6}$ & $\mathbf{2 0 1 7}$ & $\mathbf{2 0 1 8}$ & Prel. 2019 \\
\hline 1. Number of insured persons & 915 & 1.383 & 1.392 & 1.393 & 1.393 \\
\hline Social insurance & 103 & 157 & 165 & 180 & 179 \\
\hline Health insurance & 915 & 1.383 & 1.392 & 1.393 & 1.393 \\
\hline Unemployment insurance & 80 & 139 & 147 & 158 & 164 \\
\hline
\end{tabular}




\begin{tabular}{|c|c|c|c|c|c|}
\hline \multicolumn{6}{|c|}{ 2. Number of beneficiary persons } \\
\hline \multicolumn{6}{|l|}{ Social insurance (Person) } \\
\hline $\begin{array}{lll}\text { - Number of monthly social } \\
\text { insurance } \\
\text { beneficiaries }\end{array}$ & 3.278 & 1.581 & 2.452 & 3.025 & 3.200 \\
\hline $\begin{array}{l}\text { - Number of social insurance } \\
\text { recipients }\end{array}$ & 7.408 & 10.234 & 11.666 & 12.266 & 12.231 \\
\hline \multicolumn{6}{|l|}{ Health insurance (Thous. persons) } \\
\hline $\begin{array}{l}\text { - Number of health insurance } \\
\text { beneficiaries }\end{array}$ & 2.269 & 3.650 & 3.905 & 4.192 & 3.973 \\
\hline \multicolumn{6}{|l|}{ Unemployment insurance } \\
\hline $\begin{array}{l}\text { Number of } \\
\text { unemployment } \\
\text { beneficiaries (Person) }\end{array}$ & 1.790 & 8.075 & 8.777 & 11.245 & 13.467 \\
\hline $\begin{array}{l}\text { - Number of unemployment } \\
\text { insurance recipients, vocational, job } \\
\text { seeking (Person) }\end{array}$ & 125 & 152 & 215 & 182 & 386 \\
\hline \multicolumn{6}{|c|}{ 3. Number of beneficiaries of voluntary unemployment insurance } \\
\hline - Number of insured person & 3,308 & 2,287 & 2,392 & 2,138 & $\mathrm{n} / \mathrm{a}$ \\
\hline - Ratio to total targeted persons (\%) & 0.37 & 0.34 & 0.36 & 0.24 & $\mathrm{n} / \mathrm{a}$ \\
\hline
\end{tabular}

Balance of insurance revenue and expenditure. Social and health insurance revenue has been increasing, on average about $12.4 \%$ per year in the period 2015-2019. Total insurance revenue reached nearly 4.2 trillion VND in 2019, an increase of 5.9\% compared to 2018 . Social insurance revenue has accounted for a biggest proportion, over $60 \%$ of total insurance revenue in 2019 (growing by 14.6\%). Unemployment insurance revenue tends to increase, rising 94 billion dong in 2015 to 182 billion VND in 2019 (augmenting by 14.2\% compared to 2018 ) but contributing $4.4 \%$ of total insurance revenue.

Table 3. Balance of insurance revenues and expenditures in 2010-2019. Unit: Bill. dongs (Source: Quang Nam statistical yearbook 2018, 2019).

\begin{tabular}{|l|c|c|c|c|c|c|}
\hline & $\mathbf{2 0 1 0}$ & $\mathbf{2 0 1 5}$ & $\mathbf{2 0 1 6}$ & $\mathbf{2 0 1 7}$ & $\mathbf{2 0 1 8}$ & Prel. 2019 \\
\hline 1. Total revenues & $\mathbf{8 7 1}$ & $\mathbf{2 . 4 6 8}$ & $\mathbf{2 . 8 9 7}$ & $\mathbf{3 . 2 7 9}$ & $\mathbf{3 . 8 0 9}$ & $\mathbf{4 . 1 6 8}$ \\
\hline Social insurance & 450 & 1.428 & 1.675 & 1.967 & 2.231 & 2.557 \\
\hline Health insurance & 378 & 924 & 1.099 & 1.168 & 1.418 & 1.429 \\
\hline Unemployment insurance & 43 & 94 & 116 & 137 & 160 & 182 \\
\hline 2. Total expenditures & $\mathbf{8 1 4}$ & $\mathbf{2 . 3 8 4}$ & $\mathbf{2 . 8 4 9}$ & $\mathbf{3 . 8 3 6}$ & $\mathbf{3 . 7 7 4}$ & $\mathbf{4 . 1 9 1}$ \\
\hline Social insurance & 488 & 1.273 & 1.405 & 1.849 & 2.137 & 2.410 \\
\hline Health insurance & 322 & 1.060 & 1.383 & 1.910 & 1.637 & 1.633 \\
\hline Unemployment insurance & 4 & 51 & 61 & 76 & - & 148 \\
\hline 3. End-year surplus & $\mathbf{5 7}$ & $\mathbf{8 5}$ & $\mathbf{4 8}$ & $\mathbf{- 5 5 7}$ & $\mathbf{- 1 2 4}$ & $\mathbf{- 2 3}$ \\
\hline Social insurance & -37 & 155 & 270 & 118 & 94 & 147 \\
\hline Health insurance & 56 & -136 & -284 & -742 & -219 & -204 \\
\hline Unemployment insurance & 38 & 43 & 55 & 60 & - & 34 \\
\hline
\end{tabular}

Total insurance expenditures have been increasing, reached nearly 4.2 trillion VND in 2019 , an increase of $11.1 \%$ compared to 2018. Social insurance expenditure has accounted for a biggest proportion (57,5\% of total insurance expenditures in 2019) compared to health insurance expenditure (contributing 39\%) and unemployment insurance expenditure (sharing 3.5\%).

The insurance fund of Quang Nam province has been facing an overspending. Total cumulative overspending budget was about 500 billion dong in the period of 2015-2019. In 2017, there were 1,832 agencies in Quang Nam did not paid social insurance for over 64 thousand employees, which are mainly non-sate companies and individual businesses. Total debts of social insurance, health insurance, unemployment insurance were about 97,000 
billion VND and the rate of debts was 6.42 percent in 2017 (see Table 4 and Table 5).

Table 4. Number of unanticipated labors and agencies in social insurance in 2017 (Source: Quang Nam Social Insurance and Department of Taxation).

\begin{tabular}{|c|c|c|c|c|c|c|}
\hline \multirow[b]{2}{*}{ Contents } & \multicolumn{5}{|c|}{ Types of agencies } & \multirow[b]{2}{*}{ Total } \\
\hline & $\begin{array}{c}\text { State } \\
\text { owned } \\
\text { enterprises }\end{array}$ & $\begin{array}{c}\text { Non-state } \\
\text { enterprises }\end{array}$ & $\begin{array}{c}\text { Foreign } \\
\text { investment } \\
\text { enterprise }\end{array}$ & $\begin{array}{l}\text { Coope- } \\
\text { ratives }\end{array}$ & $\begin{array}{c}\text { Individual } \\
\text { business }\end{array}$ & \\
\hline $\begin{array}{l}\text { a. Number of } \\
\text { unanticipated } \\
\text { agencies } \\
\text { 2) }\end{array}$ & 0 & 1,496 & 3 & 43 & 290 & 1,832 \\
\hline $\begin{array}{l}\text { - Number of } \\
\text { agencies pay } \\
\text { tax (1) }\end{array}$ & 6 & 3,500 & 136 & 121 & 370 & 4,133 \\
\hline $\begin{array}{l}\text { - Number of } \\
\text { agencies pay } \\
\text { social } \\
\text { insurance } \\
\text { fees (2) }\end{array}$ & 6 & 2,004 & 133 & 78 & 80 & 2,301 \\
\hline $\begin{array}{l}\text { b. Number of } \\
\text { unanticipated } \\
\text { labors (3-4) }\end{array}$ & 10 & 62,040 & 259 & 189 & 1,792 & 64,290 \\
\hline $\begin{array}{l}\text { - Number of } \\
\text { labors pay } \\
\text { personal } \\
\text { income tax } \\
(3)\end{array}$ & 390 & 130,000 & 38,800 & 810 & 2,550 & 172,550 \\
\hline $\begin{array}{l}\text { - Number of } \\
\text { labor pay } \\
\text { social } \\
\text { insurance } \\
\text { fees (4) }\end{array}$ & 380 & 67,960 & 38,541 & 621 & 758 & 108,260 \\
\hline
\end{tabular}

Table 5. Debt situation of social insurance, health insurance, unemployment insurance of companies and cooperatives in Quang Nam. Unit: Bill. dongs (Source: Quang Nam Social Insurance and Department of Taxation).

\begin{tabular}{|c|l|c|c|c|c|c|}
\hline No & \multicolumn{1}{|c|}{ Year } & $\mathbf{2 0 1 3}$ & $\mathbf{2 0 1 4}$ & $\mathbf{2 0 1 5}$ & $\mathbf{2 0 1 6}$ & $\mathbf{2 0 1 7}$ \\
\hline 1 & Total unearned revenue & 584.327 & 772.379 & 944.835 & $1,248.614$ & $1,509.785$ \\
\hline 2 & $\begin{array}{l}\text { Total debts of social } \\
\text { insurance, health } \\
\text { insurance, } \\
\text { unemployment } \\
\text { insurance }\end{array}$ & 64.136 & 76.149 & 67.347 & 86.227 & 96.975 \\
\hline 3 & $\begin{array}{l}\text { Debt ratio (total } \\
\text { debt/total unearned } \\
\text { revenue) }\end{array}$ & $10.97 \%$ & $9.86 \%$ & $7.13 \%$ & $6.9 \%$ & $6.42 \%$ \\
\hline
\end{tabular}

However, the implementation of insurance policies has experienced limitations and weakness, for instance: number of insured people are relatively low; the situation of insurance arrears and evasion has still remained; insurance fund, especially health insurance fund have been overspending recently.

\subsection{Pension, social allowances and social assistances}


The payment of pension and allowances of social insurance has been implemented sufficiently. Table 6 shows that number of people received pension and allowances of social insurance have accounted for a big proportion, over $44.1 \%$ of total beneficiary persons in 2017. The rate of direct receiving method is higher than the rate of ATM receiving one. Number of people receiving pension and allowances of social insurance through ATM accounted for 14.9 percent of total recipients in 2017.

Table 6. Total expenditure for pension and allowances of social insurance in December 2017 in Quang Nam Source: Quang Nam Social Insurance).

\begin{tabular}{|c|c|c|c|c|c|c|c|}
\hline \multirow{3}{*}{ Sources } & \multicolumn{3}{|c|}{$\begin{array}{l}\text { Number of people received } \\
\text { pension and allowances of social } \\
\text { insurance }\end{array}$} & \multicolumn{3}{|c|}{ Number of recipients through ATM } & \multirow[t]{3}{*}{ Note } \\
\hline & \multirow{2}{*}{$\begin{array}{c}\text { Total } \\
\text { (person) }\end{array}$} & \multicolumn{2}{|c|}{ Of which: } & \multirow{2}{*}{$\begin{array}{c}\text { Total } \\
\text { (person) }\end{array}$} & \multicolumn{2}{|c|}{ Of which: } & \\
\hline & & Pension & Allowance & & Pension & Allowance & \\
\hline $\begin{array}{l}\text { State } \\
\text { budget }\end{array}$ & 12.791 & 10.872 & 1.919 & 520 & 484 & 36 & $\begin{array}{c}> \\
1995\end{array}$ \\
\hline $\begin{array}{l}\text { Social } \\
\text { insurance } \\
\text { fund }\end{array}$ & 16.159 & 15.028 & 1.131 & 3.793 & 3.745 & 48 & $\begin{array}{c}< \\
1995\end{array}$ \\
\hline Total & 28.950 & 25.90 & 3.050 & 4.313 & 4.229 & 84 & \\
\hline
\end{tabular}

The whole province has regularly implemented policies and orders for people who are subjected social protection by regulations. In the period of 2015-2019, the province implemented community-based care allowances for 495,262 social protection beneficiaries with a total expenditure of 2.281 billion VND. In addition to monthly social allowances, social protection beneficiaries receive health insurance cards for free and allowances for funeral and burial costs upon their death with an amount of 5.4 million VN per person. The province issues, on average, about 70 thousand health insurance cards for free per year for those whose health insurance premiums are $100 \%$ paid by the state budget, with a total expenditure of 50 billion VND and funeral and burial costs of 27 billion VND.

Furthermore, the province has implemented polices and other preferential regimes for people with meritorious services to the revolution. In the period of 2016-2018, the provincial government identified 4.287 beneficiaries and mobilized over VND 12 billion for "Gratitude fund". The government also mobilized agencies/companies to donate 1,314 savings books for them with a total budget of over VND 4 billion. The province organizes nursing for more than 20,000 people with meritorious services to the revolution per year. Their living conditions have been improved, nearly $97.3 \%$ of them having a living standard equal to or higher than the average living standard of provincial residents (Quang Nam People's Committee, 2018).

\subsection{Challenges in the social welfare system in Quang Nam for 2021-2030}

Based on analyzing the current situation of the two out of the four principal pillars of the system, including finance and delivery, two primary challenges currently faced by Quang Nam as follows:

According to Quang Nam Department of Finance (2019), in 2021-2025, the province budget revenue is unlikely to grow as much as the previous period since a high levy is imposed. The non-state sectors have made a large percentage of contributions to the local government budgets, accounting for around 68\% of the total in 2016-2020 (Table 7). Moreover, the current structure of the province budget revenue is unsustainable, hindering funding sources for effectively implementing social welfare policies since the revenue depends mainly on automobile assembly and manufacture by Truong Hai Auto Corporation 
(accounting for about $61 \%$ of total budget revenue from all enterprise operating in the province). Besides, enterprises in the province are chiefly small and medium enterprises (accounting for more than 90\%), making it difficult for tax revenues. In addition, tax evasion, tax debts have been pervasive. Meanwhile, investment attraction in businesses is facing increasing competitive pressure from localities in the region and around the country. Therefore, if the overspending of the insurance funds could not be well managed, securing the province's financial resources for effectively implementing social protection policies is a big challenge.

Table 7. The percentage of contributions to the state budget in Quang Nam for 2016-2020 and forecasts for 2021-2025 (Source: Compiled from the Department of Finance's reports (2019)).

\begin{tabular}{|l|c|c|c|c|}
\hline \multirow{2}{*}{ Economic sectors } & \multicolumn{2}{|c|}{ In 2016-2020 } & \multicolumn{2}{c|}{ In 2021-2025 } \\
\cline { 2 - 5 } & $\begin{array}{c}\text { Value } \\
\text { (billion } \\
\text { dong) }\end{array}$ & $\begin{array}{c}\text { Percentage } \\
\mathbf{( \% )}\end{array}$ & $\begin{array}{c}\text { Value } \\
\text { (billion } \\
\text { dong) }\end{array}$ & $\begin{array}{c}\text { Percentage } \\
\text { (\%) }\end{array}$ \\
\hline 1. Public sector & $\mathbf{4 , 3 9 3}$ & $\mathbf{4 . 6 3}$ & $\mathbf{5 , 2 4 5}$ & $\mathbf{3 . 8 4}$ \\
\hline $\begin{array}{c}\text { Central state-owned } \\
\text { enterprises }\end{array}$ & 3,673 & 3.87 & 4,499 & 3.29 \\
\hline - Local state-owned enterprises & $\mathbf{7 2 0}$ & 0.76 & 746 & 0.55 \\
\hline 2. Private sector & $\mathbf{6 4 , 6 3 0}$ & $\mathbf{6 8 . 0 7}$ & $\mathbf{1 0 1 , 7 6 9}$ & $\mathbf{7 4 . 4 9}$ \\
\hline - Private enterprises & 56,364 & 59.36 & 84,619 & 61.94 \\
\hline - FDI enterprises & 8,266 & 8.71 & 17,150 & 12.55 \\
\hline $\begin{array}{l}\text { 3. Revenue from imports and } \\
\text { exports }\end{array}$ & $\mathbf{2 5 , 9 2 8}$ & $\mathbf{2 7 . 3 1}$ & $\mathbf{2 9 , 6 0 0}$ & $\mathbf{2 1 . 6 7}$ \\
\hline Total revenue & 94,951 & 100.00 & 136,614 & 100.00 \\
\hline
\end{tabular}

Firstly, state funding for implementing social welfare policies is likely to shrinks. In fact, spending on social welfare comprises a small proportion of the total state expenditure in the province (about $6.28 \%$ in 2018). Nonetheless, effective implementation of the social welfare policies is considered as one of the crucial indicators, demonstrating successful execution of the province's economic restructuring. This expenditure is forecasted to rise while the budget revenue in 2020-2025 are predicted not to increase as much as in it did the previous period. If the province is unable to attract investment projects or large enterprises, this situation will become a serious challenge in the coming period.

Secondly, budget revenue from insurance are declining since low percentages of enrolment in social insurance are observed. Goals are set as follows: By 2025, 45\% of the working-age population will participate in social insurance; nearly $2.5 \%$ of informal workers will participate in voluntary social insurance; roughly $35 \%$ of the working-age population will join unemployment insurance. Those challenges require breakthrough solutions to promoting labor restructuring that is parallel with the economic restructuring.

Thirdly, debts in social insurance, health insurance, and unemployment insurance comprise a high rate since numerous employers avoid paying their employees insurance contributions or paying for compulsory social insurance is insufficient. The latter could be performed via two major forms namely concealing labor contracts or providing a misleading payroll that does not match their employees' reported taxable income; deliberately falsifying data and records of evidence to reduce tax by increasing costs and decrease the revenue.

Fourthly, the cost of covering policies on poverty reduction, subsidies, and social incentives is relatively high and keeps rising. The high rate of the province's poor households and numerous people to be protected has burdened the province with a large amount of annual payment for beneficiaries compared to other provinces in the South Central Viet Nam.

Regarding beneficiaries, identifying and managing beneficiaries, particularly old-age 
pensioners and social insurance recipients, is viewed as an obstacle for Quang Nam. Typical cases can be included as follows: Receiving money on a beneficiary's behalf without any power of attorney, insufficient information of beneficiaries entitled to monthly social insurance benefits due in part to free residence facilitated or to making a payment via bank transfer. Besides, investigating and identifying poor households in many places does not comply with current regulations. In addition, excessive reliance on state support is quite common. Furthermore, staff members in charge of executing social policies, especially at local government, are unqualified or lack of professional skills required.

Levels of delivery including the amount of money and quality of services are predicted to become more and more difficult due to limited subsidies and social protection. In the coming years, as people's living standards are increasingly improved (GRDP per person is targeted at 5,000 USD by 2025), allowance levels of social insurance and quality of social welfare services is required to be enhanced accordingly. Besides, the expansion of various groups of participants in voluntary social insurance is confronting various challenges. For instance, under the regulations of voluntary social insurance, eligibility for pension benefits requires at least 20 years of accumulated participation while coverage remains low. In addition, this regulation of insurance discourages all targeted people to participate in social insurance. Furthermore, communication and propagation of the regulation is not paid much attention, resulting in insufficient information provided for participants. Moreover, an inadequate network of services is seen as a weakness of voluntary social insurance. Despite the improved health system, local people's demand is not satisfied.

\subsection{Discussion and conclusion}

Social welfare policies should be expanded to the extent that can be covered by public finance in case of fiscal imbalance. Given challenges, it is crucial for Quang Nam to run the following solutions in an effort to balance the medium and long-term financial resources.

Firstly, public expenditures on social welfare should be modified for the sake of balancing employers' benefits, their employees, and other groups of the population. In that sense, fairness and justice will be ensured and promoted, earning people's trust and encouraging participation in the social insurance system.

Secondly, coverage of mandatory social insurance and voluntary social insurance should be expanded in terms of contributions of employees and employers for the former as well as workers who are not provided a labor contract for the latter. Measures can be considered such as restrictive measures (sanctions) are essential for enterprises that do not pay for social insurance; promoting mass media communications to raise public awareness of various benefits of participating in diverse types of insurance.

Thirdly, local government should diversify insurance fund resources from various social resources by calling for contributions from numerous enterprises, organizations, individuals, and external resources such as ODA, non-refundable aid from other countries.

Fourthly, policies on promoting production and trade should be paid much attention by effectively organizing investment promotion activities to attract domestic and foreign investments. Accordingly, the provincial budget revenue rise and coverage of different types of insurance is expanded.

Fifthly, the province needs to form sound policies on encouraging individuals to join the labor market through training, vocational guidance, and employment consultation in case of increasing unemployment.

Besides, the province should make predictions about employment transition from the farm sector to non-farm one, the trend of aging population so that revenue and expenditure on implementing social welfare policies is likely to be projected.

Implementing effectively social welfare policies is a key factor in earning local people's 
trust. The local government should pay much attention to various solutions to delivery of social welfare as below:

Firstly, to raise public awareness of health insurance and health care through mass media communications about diverse benefits of participating in insurance. The province should consider establishing public relations division that practices varied public relations strategies and helps people more easily access insurance services with a wide range of methods.

Secondly, to improve the quality and efficiency of the health care system by increasing investment in health infrastructure, medical equipment, and medical staff. Besides, the province should focus on improving medical staff's attitude to satisfy patients as well as enhancing their communication and consultation skills in health services.

Thirdly, to seriously and effectively manage old-age pensioners and social insurance beneficiaries under current regulations. The province should focus more on supervising of beneficiaries through payment. Besides, insurance payers need to regularly coordinate with organizations and individuals to be well updated on any change in the number of beneficiaries in case they leave their permanent residence, are reported missing, or died. In addition, the application of information technology in payment for beneficiaries should be promoted to ensure flexibility and transparency, contributing to managing beneficiaries efficiently as well as simplifying administrative procedures.

Fourthly, beneficiaries who are elderly, weak, sick, lonely, and not able to receive their pensions/ social insurance allowances directly at payment points, or authorize another person on their behalf should be paid at their houses.

Fifthly, to raise beneficiaries' awareness of their responsibility so that allowances can reach the right beneficiaries. There happens a situation in which beneficiaries who left their places a long time ago, were reported missing, or dies still receive their pensions/ social insurance allowances. This incident drains the insurance fund as well as decreasing public trust in the insurance fund in the province.

Socialization and encouragement of the non-state sector's participation in implementing social welfare policies is a comprehensive and long-term solution. As the local economy develops, its people's living conditions are improved. Nevertheless, it is accompanied by potential risks such as unemployment, inequality, and social problems. Accordingly, demand for social welfare has been increasing in terms of both quality and quantity. Hence, socialization which is a primary feature of the social welfare system in the market economy is becoming more and more critical, particularly community development, poverty alleviation, and social assistance. Such a process requires the state to play a leading role in forming institutions for enterprises and its people to exercise their rights and fulfill their obligations under the regulations. Besides, the state should promote mass media communications and raise public awareness of implementing social welfare policies.

\section{References}

1. W.H. Beveridge, Insurance for All and Everything (The Daily News LTD, London, 1924)

2. Bui Sy Loi, Social Sciences Review 8 (2010)

3. N. Gilbert, P. Terrell, Dimensions of Social Welfare Policy (Allyn and Bacon, Boston. MA, 2002)

4. Huu Diep, Labor and Social Review 3 (2018)

5. Kim Anh, Development of participants in social insurance, health insurance and debt recovery in coordination with Tax authorizes, Web of Quang Nam Social Insurance (2018) 
6. Mac Tien Anh, Social Insurance Review 1 (2005)

7. Park Jin et al., Economic System in Vietnam: Social welfare system, Development Experience Exchange Partnership (DEEP) with Korea (2018)

8. Report on the results of implementing Resolution of the XXI provincial Party's General meeting (2015-2020), directions and tasks for 5 years (2020-2025) (Quang Nam Department of Labors, War Invalids and Social Affairs, 2019)

9. Report on evaluating the indicators of state budget revenue in the period of 2016-2020 and suggesting state budget revenue indicators for 2012-2025 in Quang Nam province (Quang Nam Department of Finance, 2019)

10. Master plan of social economic development in Quang Nam upto 2020, with a vision to 2030 (Quang Nam People's Committee, 2015)

11. Report on the results of social economic development in mid-term (2016-2018) of Resolution No.177/2015/NQ-HĐND dated 11/12/2015 (Quang Nam People's Committee, 2018)

12. Quang Nam Statistical Yearbook 2018

13. Quang Nam Statistical Yearbook 2019 